\title{
Characterization and in vitro susceptibility profile of bacterial samples harvest from canine chronic otitis
}

\author{
[Caracterização e avaliação da susceptibilidade in vitro de bactérias oriundas de otites crônicas de cães]
}

\section{"Scientific Article/Artigo Científico"}

\author{
Jorge Bárcena Barriuso ${ }^{1}$, Deivid Roni Ribeiro ${ }^{1}$, Javier Felipe Burchard ${ }^{2}$, Kung Darh Chi $^{1}$, \\ Amanda Anater ${ }^{1}$, Marconi Rodrigues de Farias ${ }^{1}$, Cláudia Turra Pimpão ${ }^{1 *}$
}

\author{
${ }^{1}$ School of Life Sciences, Pontifícia Universidade Católica do Paraná, Curitiba-PR, Brasil. \\ ${ }^{2}$ Council on Dairy Cattle Breeding, Bowie-MD, Estados Unidos da América. \\ *Corresponding author/Autora para correspondência: E-mail: claudia.pimpao@ pucpr.br
}

\begin{abstract}
This study aimed to identify which are the most frequent bacteria evolved in cases of chronic otitis in dogs in the metropolitan region of Curitiba, as well to determine their in vitro antimicrobial susceptibility. Data of positive bacterial culture from dogs affected by chronic or recurrent otitis were compiled from the records of the veterinary hospital of Pontifícia Universidade Católica do Paraná, Curitiba, southern Brazil. In a period of 16 months, a total of 83 bacterial cultures were performed, resulting in 192 isolates. All isolates were submitted to antimicrobial susceptibility tests, based on the Kirby-Bauer technique using 17 drugs from 8 antibiotic classes ( $\beta$-lactams, aminoglycosides, lincosamides, macrolides, polypeptides, quinolones, tetracyclines, and amphenicols). The five most frequent bacterial isolates were Staphylococcus spp. (58.32\%), Proteus spp. (14.58\%), Escherichia coli (9.90\%) and Pseudomonas spp. (8.33\%). The four most effective antibiotics were amikacin (13.29\%), neomycin (24.47\%), gentamicin $(25.52 \%)$ and tobramycin (26.70\%); however, these aminoglycosides may cause ototoxicity, and their use should be restricted when the tympanic membrane is intact. Quinolones also showed antimicrobial effectiveness, with $29.17 \%$ of the isolates showing resistance to ciprofloxacin and $29.69 \%$ to enrofloxacin. According to the results, it can be concluded that aminoglycosides and quinolones were effective against microorganisms of canine chronic otitis.
\end{abstract}

Keywords: aminoglycosides; antibiogram; ototoxicity; quinolones; Staphylococcus spp.

\section{Resumo}

Este estudo teve por objetivo identificar quais as bactérias mais frequentemente envolvidas em casos de otites crônicas em cães da região metropolitana de Curitiba, assim como determinar sua susceptibilidade antimicrobiana in vitro. Dados de culturas bacterianas positivas, oriundas de cães acometidos por otite crônica ou recorrente foram compilados dos arquivos do hospital veterinário da Pontifícia Universidade Católica do Paraná, sul do Brasil. De um período total de 16 meses, foram obtidas 83 culturas bacterianas positivas, totalizando 192 isolados. Todas as cepas isoladas foram submetidas a provas de sensibilidade antimicrobiana baseadas na técnica de Kirby-Bauer, utilizando 17 drogas de 8 famílias antibióticas ( $\beta$-lactâmicos, aminoglicosídeos, lincosaminas, macrolídeos, polipeptídeos, quinolonas, tetraciclinas e cloranfenicol). As cinco espécies bacterianas mais frequentes foram Staphylococcus spp. (58,32\%), Proteus spp. (14,58\%), Escherichia coli $(9,90 \%)$ e Pseudomonas spp. (8,33\%). Dos antibacterianos testados, os quatro que apresentaram menor índice de resistência foram amicacina $(13,29 \%)$, neomicina $(24,47 \%)$, gentamicina $(25,52 \%)$ e tobramicina $(26,70 \%)$; porém, todos eles são aminoglicosídeos e podem causar ototoxicidade, sendo que seu uso deve ser restringido para casos em que haja integridade da membrana timpânica. As quinolonas também apresentaram baixa resistência, com 29,17\% dos isolados sendo resistentes à ciprofloxacino e $29,69 \%$ à enrofloxacino. De acordo com os dados obtidos, pode-se concluir que os aminoglicosídeos e as quinolonas mostraram-se mais efetivos contra as bactérias encontradas em otites 
crônicas de cães causadas por microrganismos, principalmente em tratamentos empíricos ou em casos que não seja possível realizar uma cultura e antibiograma, apesar de não ser o recomendado.

Palavras-chave: aminoglicosídeos; antibiograma; ototoxicidade; quinolonas; Staphylococcus spp.

\section{Introduction}

Otitis is considered a common disease of pets in veterinary practice. It causes great discomfort to animals and owners, as it can cause pain, itching, agitation, discharge and unpleasant odor. However, cases of canine otitis are often neglected by professionals due to a lack of accurate diagnosis and essential examinations such as bacterial culture and antibiogram of otological secretions (Miller et al., 2013).

Otitis is considered a complex disease, since it usually involves more than one etiological component, complicating the diagnosis of the primary factors, as well as the treatment to be utilized (Miller et al., 2013; Griffin, 2014a; Griffin, 2014b).

According to Harvey et al. (2004), canine otitis can be classified as externa, media and interna, considering ear portions and anatomic structures that are affected. It can also be classified according to their laterality (unilateral or bilateral) and clinical evolution (acute, chronic or chronic recurrent). The chronic recurrent type represents up to $76.7 \%$ of otitis cases (Marinho et al., 2009).

To make a correct diagnosis of otitis cases, a systematic and complete investigation of the possible causal agents is needed. The investigation should always include anamnesis, physical examination, otoscopy and sample smear for cytopathology of the auricular secretion (Matousek, 2004; Luz et al., 2014). Cytopathology is a fast, inexpensive and simple technique that offers a lot of information, being very important in the diagnosis, since it allows to identify yeasts, bacteria, keratin debris, cerumen, inflammatory cells and other cells (Colombini, 2005; Bensignor, 2008; Zur, 2014).

However, sometimes cytopathology can be ineffective to guide the treatment, thus whenever possible, it is important to perform microbial culture and antibiogram, particularly in chronic cases. These tests can lead to a more accurate diagnosis and better therapeutic response, since it allows the identification of the microbial agent and the most effective antimicrobial (Jacobson, 2002; Girão et al., 2006; Malayeri et al., 2010).
Regarding chronic otitis, it is necessary to diagnose, treat or correct its primary, predisposing, and perpetuating etiological factors, i.e., identifying bacteria, yeasts, and progressive pathological alterations (Gotthelf, 2007; Miller et al., 2013; Griffin, 2014b), thereby reinforcing the importance of microbial culture.

Due to the intense empirical use of antimicrobials, an increase in the number of drug associations by the pharmaceutical industry, and an apparent lack of antibiogram demand in the clinical practice are leading to an increase bacterial resistance in otitis cases (Zur, 2014; Cheng et al., 2015).

The objective of this study was to identify the profile of microbial agents causing chronic otitis in dogs diagnosed in the metropolitan region of Curitiba, as well as to evaluate the in vitro susceptibility of strains in front of different antimicrobials.

\section{Material and Methods}

A prospective study with clinical samples was carried out for the epidemiological evaluation of the bacteria isolated from the chronic or recurrent otitis in dogs, during a period of 16 months. The animals were diagnosed and treated at the Veterinary Hospital of the Pontificia Universidade Católica do Paraná (PUCPR).

Adult dogs diagnosed with chronic or recurrent and unilateral or bilateral otitis, were selected regardless of breed and gender. Based on the presence of erythema on the concave portion of the auricular pinna and auditory canals, excessive production of cerumen and/or the presence of pus, auricular pruritus and/or headaches over a period of more than 30 days or intermittent episodes; as well as animals with signs of chronicity, such as epithelial hyperplasia, excess skin folds, fibrosis, calcification and stenosis of the ducts that presented a positive cytological diagnosis for the presence of bacteria and a positive bacterial culture.

Animals with acute otitis (less than 30 days of evolution), with no detectable microorganisms from bacterioscopy nor microbial growth on bacterial cultures, were excluded from the study. 
All the animals underwent complete evaluation consisting of anamnesis, emphasizing the data on the clinical and epidemiological aspects of otitis in order to determine the time of evolution of the clinical picture. A direct inspection was performed on both ears to detect any signs of chronic otitis: epithelial hyperplasia, presence of skin folds, fibrosis and stenosis of ducts. In addition, all animals went through otoscopic examination in which the otoscope was introduced into the vertical conduit and, when possible, in the horizontal conduit to determine the presence or absence of edema, erythema, exudation, foreign body, neoplastic nodules or tumors, stenosis and the integrity and aspects of the tympanic membrane, and the examination was repeated in both ducts.

\section{Cytopathological examination}

In cases where the presence of any type of secretion or exudate was evident, a sample of the otological secretion of the affected ear(s) was collected with the aid of a non-sterile swab for cytopathology; the smear was performed by spreading the sample on the glass slide by rotating the swab on the surface and then allowing it to dry for 5-10 minutes at room temperature until the surface of the secretion was completely dry. After drying, the slides were stained with rapid panoptic staining (Instant Prov $\left.^{\circledR}\right)^{1}$.

The sample was observed under a microscope at 1000x magnification (immersion objective) to visualize the possible bacteria. It was possible to diagnose if the otitis was of bacterial origin or not, and, in cases of bacterial otitis, to determine if they were aggravated by the growth of bacteria of cocci or bacilli shapes.

Once the presence of bacteria was observed in cytopathology, a new sample of auricular secretion was collected in sterile form; for this a sterile swab was placed in the vertical portion of the auricular canal or, when possible, in the horizontal portion. This swab was wrapped in a plastic tube with Stuart's medium inside and later sent for bacterial culture and antibiogram at the microbiology laboratory of the Veterinary Hospital of PUCPR. In cases of bilateral bacterial otitis, this procedure was repeated in the contralateral conduit.

\section{Culture and bacterial identification}

All the positive cytopathology samples, or in bilateral otitis, samples of both ears were inoculated in 5\% sheep blood agar Petri-dish and in MacConkey agar Petri-dish. and incubated at $37^{\circ} \mathrm{C}$ for 24-48 hours. Observations were made every 24 hours of incubation. Cultures that could not grow in a maximum period of 48 hours were considered negative.

In positive cases, the identification would be based on colony morphology, Gram staining characteristics, enzymatic tests, biochemical profile (Quinn et al., 2011) characterized by a commercial kit for enterobacteria (NewProv, Produtos para Laboratórios, Pinhais, Brasil) and for non-fermenting bacteria (NewProv, Produtos para Laboratórios, Pinhais, Brasil) to determine Gramnegative genera.

Figure 1 shows the schematic of the protocol performed to identify the different bacterial species.

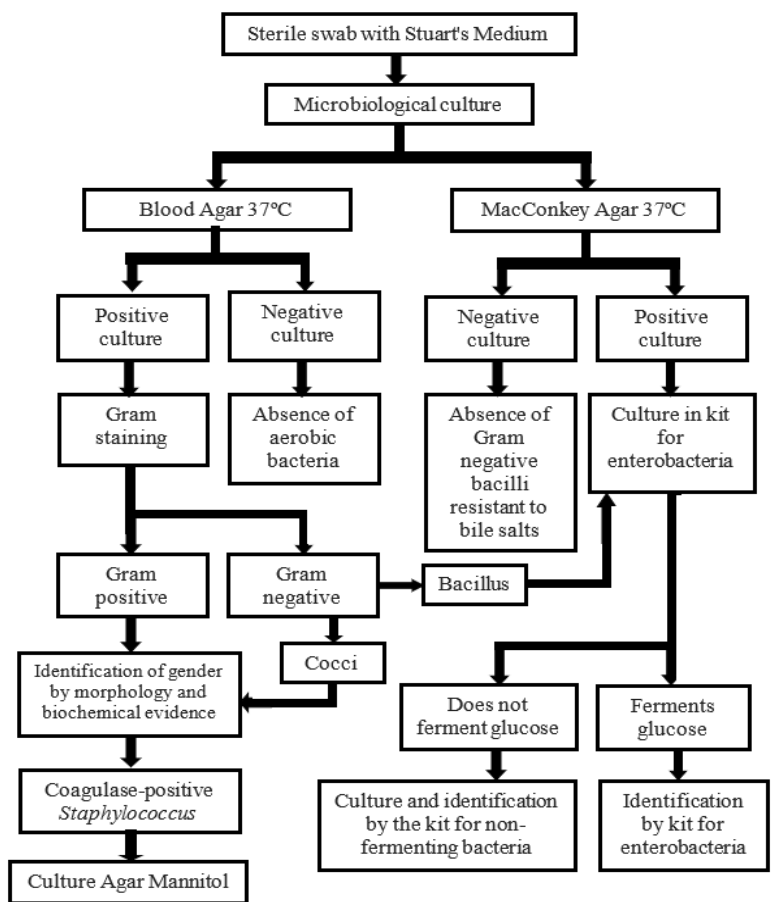

Figure 1. Protocol for the identification of different bacterial species.

\section{Antibiogram}

Based on the technique described by Kirby and Bauer (Bauer et al., 1966), antimicrobial susceptibility tests were performed on each isolate using the following drugs: cefalexin, cefovecin, amoxicillin + clavulanic acid, ampicillin, penicillin G, amicacine, streptomycin, gentamicin, neomycin, tobramycin, lincomycin, erythromycin, polymyxin B, ciprofloxacin, enrofloxacin, doxycycline and chloramphenicol.

In total, 17 antibiotics divided into eight groups were tested, as shown in Table 1. 
Table 1. Groups, classes and antibiotics used for antimicrobial susceptibility testing.

\begin{tabular}{ccc}
\hline Groups & Classes & Antibiotics \\
\hline 01 & $\beta$-Lactams & $\begin{array}{c}\text { Amoxicillin with clavulanic acid (AMC), ampicillin (AMP), cephalexin } \\
(\text { CPX), ceforecin (CFN), and penicillin G (PEN) }\end{array}$ \\
02 & Aminoglycosides & $\begin{array}{c}\text { Amicacin (AMI), streptomycin (STR), gentamicin (GEN), neomycin } \\
(\text { NEO), and tobramycin (TOB) }\end{array}$ \\
03 & Lincosamides & Lincomycin (LIN) \\
04 & Macrolides & Erythromycin (ERY); \\
05 & Polypeptides & Polymyxin B (POL); \\
06 & Quinolones & Ciprofloxacin (CIP) and enrofloxacin (ENO) \\
07 & Tetracyclines & Doxycycline (DOX) \\
08 & Amphenicols & Chloramphenicol (CLO)
\end{tabular}

\section{Statistical analysis}

For statistical analysis of epidemiological data and in vitro susceptibility to antimicrobials, Fischer's exact test or the Chi-square test were used to evaluate the association between qualitative variables. All data were described in percentage and statistical software GraphPad Prism, version 5.00 for Macintosh ${ }^{\circledR}$, San Diego - California, USA was used. The level of significance was set at $5 \%$ $(\mathrm{p}<0.05)$ (Petrie and Watson, 2009).

\section{Results}

The study included 70 animals, 40 females $(57.14 \%)$ and 30 males $(42.86 \%)$, and no difference $(\mathrm{p}=0.4980)$ was found for gender.

Of all the animals evaluated, $25.71 \%$ (18) were crossbred animals; $15.71 \%$ (11) were Lhasa Apso; 10\% (7) Poodle; 5.71\% (4) Cocker; 5.71\% (4) Labrador Retriever; $5.71 \%$ (4) Pit Bull; $5.71 \%$ (4) Shar-pei; $4.29 \%$ (3) Yorkshire Terrier; $2.86 \%$ (2) Maltese Bichon; 2.86\% (2) Pinscher; $2.86 \%$ (2) Pug; $2.86 \%$ (2) Rottweiler; $1.43 \%$ (1) Boxer; $1.43 \%$ (1) Dachshund; $1.43 \%$ (1) Golden Retriever; $1.43 \%$ (1) German Shepherd; $1.43 \%$ (1) Swiss Shepherd; $1.43 \%$ (1) Shi Tzu and $1.43 \%$ (1) West Highland White Terrier.

\section{Microbiology of otological secretion of dogs with chronic otitis}

Of the 70 animals evaluated, $11.46 \%$ (8) had to repeat the culture at least once because of recurrences, so a total of 83 cultures with bacterial growth were obtained.

In relation to laterality, $65.10 \%$ (54) of the cultures came from bilateral otitis and $34.90 \%$ (29) from unilateral otitis. Among unilateral otitis, $62.06 \%(18 / 29)$ were from the right ear and $37.94 \%$ (11/29) from the left ear; a total of 137 ear cultures were performed without significant difference between the affected sides $(\mathrm{p}=0.7179)$.

A total of 192 bacterial isolates were obtained from the 137 ears cultures; $53.64 \%$ $(103 / 192)$ were from the right ear and $46.35 \%$ (89/192) were from the left ear, but without significant difference $(\mathrm{p}=0.5401)$.

Regarding bacterial identification (Figure 2), the 192 isolates were classified as $58.32 \%$ (112) Staphylococcus spp., $14.58 \%$ (28) Proteus spp., 9.90\% (19) Escherichia coli, 8.33\% (16) Pseudomonas spp. and reported with less frequency $2.08 \%$ (4) Bacillus spp., $2.08 \%$ (4) Streptococcus spp., $1.56 \%$ (3) Corynebacterium spp., $1.56 \%$ (3) Serratia spp., $0.52 \%$ (1) Acinetobacter spp., $0.52 \%$ (1) Enterobacter spp. and $0.52 \%$ (1) Morganella spp.

In vitro antimicrobial susceptibility tests were performed for all isolates using previously mentioned drugs: cefalexin (CFX; 192), cefovecin (CVN; 72), amoxicillin with clavulanic acid (AMC; 189), ampicillin (AMP; 192), penicillin G (PEN; 191), amicacin (AMI; 158), streptomycin (STR; 181), gentamicin (GEN; 192), neomycin (NEO; 192), tobramycin (TOB; 191), lincomycin (LIN; 136), erythromycin (ERY; 192), polymyxin B (POL; 192), ciprofloxacin (CIP; 192), enrofloxacin (ENO; 192), doxycycline (DOX; 184) and chloramphenicol (CLO; 186).

Regarding the in vitro bacterial susceptibility to $\beta$-lactams, $35.94 \%$ (69/192) were resistant to CFX; $48.61 \%$ (35/72) to CVN; $31.75 \%$ (60/189) to AMC; $65.96 \%$ (124/192) to AMP and $76.44 \%$ (146/191) presented resistance to PEN.

In the aminoglycoside class, $13.29 \%$ (21/158) were resistant to AMI; $44.20 \%$ (80/181) to STR; $25.52 \%(49 / 192)$ to GEN; $24.48 \%$ (47/192) to NEO and $26.70 \%(51 / 191)$ were resistant to TOB. 


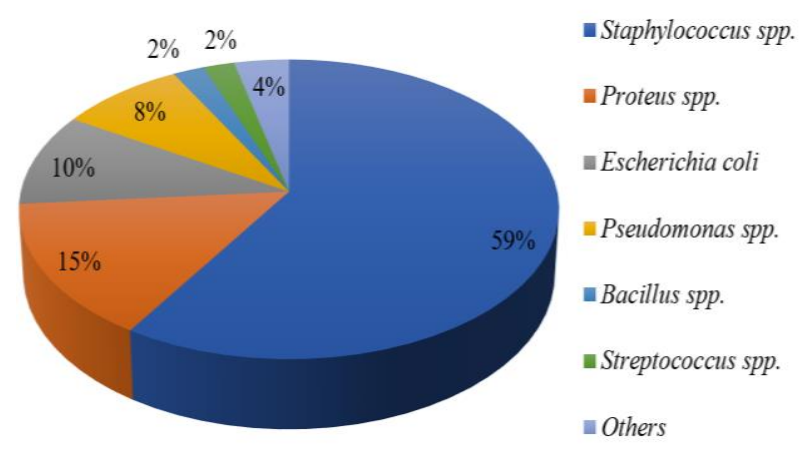

Figure 2. Distribution of different bacterial species isolated from chronic otitis in dogs from the Veterinary Hospital of Pontifícia Universidade Católica do Paraná (PUCPR).

In the lincosamine class, $67.65 \%(92 / 136)$ were resistant to LIN; in the macrolide class, there was a resistance to ERY in $65.63 \%(126 / 192)$ of the cases; in the polypeptide class, $34.90 \%$ (67/192) showed resistance to POL.

Within the quinolone class, CIP presented resistance in $29.17 \%(56 / 192)$ of the samples and $29.69 \%(57 / 192)$ of the samples were resistant to ENO.

In relation to the tetracycline class, $45.65 \%$ $(84 / 184)$ of the bacterial cultures were resistant to DOX; and for the amphenicol class, $31.72 \%$ (59/186) were resistant to CLO.

\section{Antimicrobial multiresistance}

In this study the antibacterial classes tested were $\beta$-lactams, aminoglycosides, lincosamines, macrolides, polypeptides, quinolones, tetracyclines and amphenicols; of the 192 isolates, 109 (56.77\%) proved to be multiresistant.

Table 2 shows the relationship between the isolates and their resistance to at least three classes of antimicrobials tested.

\section{Discussion}

The present study did not demonstrate gender predisposition for chronic otitis. This indicates that sexual hormones have no influence over otitis occurrence. However, anatomic factors such as excess hair in the ducts, pendular ears, a natural stenosis of auditory conducts, may be predisposing factors for this (Cole, 2009; Cole, 2012).

The breeds that presented most with otitis in this study were Lhasa Apso, Poodle, Cocker, Labrador Retriever, Pit Bull and Shar-pei. In addition, Lhasa Apso and Poodle are frequently affected by atopic dermatitis, and Cocker and Labrador present primary keratinization disorders or are seboatopics, these morbidities are often involved as the primary cause of otitis (Cole, 2012).

In total, the genus Staphylococcus accounted for almost $60 \%$ of the strains isolated in this study. A possible explanation for this prevalence may be the fact that they are part of the indigenous microbiota of the healthy ear ducts (Cole, 2009), and its overgrowth occurs due to the physicalchemical changes of the ear canal and auditory canal epithelia, as well as alterations in the production of cerumen associated with the primary etiological factors of otitis in dogs (Angus, 2005; Cole, 2009).

Staphylococcus spp. was the main secondary agent of chronic otitis in dogs in the present study. Increased staphylococcal adhesion, colonization and overgrowth have been commonly observed in dogs with atopic dermatitis and primary seborrhea, suggesting that the same process occurs in the auditory ducts of these dogs and favors staphylococcal infections of a secondary nature (Oliveira et al., 2008).

Additional studies, however, are required to know whether colonization and auricular staphylococcal infection of these animals may be a source of infection to the skin, and may favor repeat infections in dogs with atopic dermatitis or with primary keratinization disorders (Oliveira et al., 2008).

Table 2. Relationship between different bacterial species and their multiresistance to at least three classes of antimicrobials used in the Veterinary Hospital of PUCPR.

\begin{tabular}{lcc}
\hline Species & $\begin{array}{c}\text { Total } \\
\text { isolated }\end{array}$ & Multiresistant \\
\hline Staphylococcus spp. & 112 & $55(49.11 \%)$ \\
Proteus spp. & 28 & $27(96.43 \%)$ \\
Pseudomonas spp. & 16 & $12(75.00 \%)$ \\
Escherichia coli & 19 & $9(47.37 \%)$ \\
Serratia spp. & 3 & $3(100.00 \%)$ \\
Acinetobacter spp. & 1 & $1(100.00 \%)$ \\
Bacillus spp. & 4 & $1(25.00 \%)$ \\
Morganella spp. & 1 & $1(100.00 \%)$ \\
\hline
\end{tabular}

Among Gram-negative bacteria isolated from chronic or recurrent otitis of the present study, Proteus mirabilis and Escherichia coli prevailed. Both are enterobacteria, and Escherichia coli is a 
bacterium specific to the intestines of dogs and other animals, including humans (Quinn et al., 2011), suggesting that the source of infection by these bacteria could be fecal and colonization from contact with the contaminated environment, water or after pruritus (Cheng et al., 2015). Another hypothesis for the origin of these bacteria is that these microorganisms colonize the ear canals of healthy dogs and, as with Staphylococcus species, infection would be the result of microbial overgrowth after otitis was established (Cole, 2009; Cole, 2012).

Pseudomonas spp. were isolated in chronic otitis in the present study less frequently than in previous studies (Hariharan et al., 2006; Penna et al., 2011; Bugden, 2013). These microorganisms originate from the environment, such as soil, water, plants; or the skin, mucous membranes and feces (Quinn et al., 2011). This lower occurrence may be explained by the fact that chronic otitis and recurrent chronic otitis in dogs are frequently related to allergic dermatopathies (Saridomichelakis et al., 2007), and in these animals the colonization of the skin by bacteria of the genus Staphylococcus is more frequent, which prevents the growth of other bacterial species (Oliveira et al., 2008).

Topical therapy is essential for the treatment of external otitis, since systemic therapy is ineffective and antibiotics administered orally or parenterally do not reach therapeutic concentrations in the fluids or exudates of the auditory ducts unless the epithelium is eroded or ulcerated in a wide region (Morris, 2004).

In the cases of otitis media, systemic therapy is necessary because the tympanic bulla is covered by a highly vascularized epithelium, which allows the medications used systemically to achieve adequate levels of antibiotic concentration (Morris, 2004).

In the present study, aminoglycosides (amicacin, neomycin, gentamicin and tobramycin), and quinolones (ciprofloxacin and enrofloxacin) were shown to be effective against more than $70 \%$ of the isolated microorganisms. This good response of aminoglycosides may be related to their wide spectrum of activity, mainly against Gram-negative bacteria (Penna et al., 2009; Magiorakos et al., 2012). The high sensitivity found for amicacin may be due to the fact that it does not have a commercial presentation available in the veterinary pharmacopoeia, and with that, it is rarely used (Magiorakos et al., 2012).
The good efficiency of neomycin, gentamicin and tobramycin, although frequently prescribed by veterinarians, can be explained by the fact that Staphylococcus spp. was the bacterial genus found in most of the chronic otitis in the present study. This genus can develop a mechanism of resistance related to $m e c \mathrm{~A}$ gene, with production of strains resistant against beta-lactam, but maintaining sensitivity to aminoglycosides (Griffin, 2014b).

Despite the high sensitivity to aminoglycosides, this class of antibiotics should be used with caution due to its ototoxic effects when administered topically in animals with ruptured tympanic membrane (Wooltorton, 2002), and because they are nephrotoxic (in addition to ototoxic) when used in a systemic way (Rang et al., 2010; Giguère et al., 2013).

Ciprofloxacin and enrofloxacin are broadspectrum antibiotics having bactericidal effects on both Gram-negative bacteria and Gram-positive bacteria. These are safe, even in cases of tympanic membrane rupture, since they are not ototoxic (Daniel and Munguia, 2008; Lemke et al., 2009), and may also be indicated for systemic use in cases of otitis media (Griffin, 2014b).

In the present study, other drugs that demonstrated good in vitro efficacy for topical use were chloramphenicol and polymyxin B. Chloramphenicol has limited use because its administration is associated with reversible and non-regenerative anemia in dogs and in humans, damage in the DNA of hematopoietic stem cells and irreversible medullary aplasia (Moraes and Takahira, 2010). The polymyxin B is a cheap molecule, widely used in medicine, but its ototoxicity limits its use exclusively to cases where there is integrity of the tympanic membrane (Morris, 2004).

Antibiotics that showed a sensitivity of less than $60 \%$ were streptomycin, doxycycline, cefovecin, erythromycin, ampicillin, lincomycin and penicillin, which contraindicates their prescription and empirical use in dogs with chronic otitis.

Some variability in antibiotic resistance can occur due to geographical differences between studies (Bugden, 2013). This can justify the difference in the findings of the present study compared to results obtained by Oliveira et al. (2005) and Penna et al. (2009), that worked in the northeast and southeast of Brazil, noticeably warmer than the southern region of Curitiba, which 
is located in the south of Brazil. Another possible justification is the inclusion criteria, since in the present study only cases of chronic and recurrent otitis, which usually have resistant or multiresistant secondary infections, were selected.

It is worth noting that all information obtained from culture and antimicrobial sensitivity tests, based on the disc diffusion method described by Bauer et al. (1966), refer to serum concentrations. However, the concentrations obtained in the topical therapies are higher than those obtained in plasma, which justifies that some bacteria considered resistant in in vitro tests are susceptible to the active principles when used in otological products in vivo (Morris, 2004).

Thus, bacteria considered partially sensitive to a given antibiotic can be considered sensitive when it is used topically and resistant to this drug in systemic therapies (Griffin, 2014b; Cheng et al., 2015).

The antibiotic that was most likely to be effective in the treatment of otitis was amicacin, but its use should be reserved for cases that do not respond to other treatments, thus reducing the risk of the onset of resistance (Moraes and Takahira, 2010).

In the present study, since only dogs with persistent chronic or chronic intermittent otitis were evaluated, there was a high incidence of bacterial multiresistance, which may be related to the widespread and indiscriminate use of antibiotics (Bugden, 2013).

The mechanisms of antibiotic resistance have been associated with the presence of specific resistance genes in plasmids, and the bacteria have the capacity to transmit this genetic material to others of the same genus and species, as well as to other phylogenetically distant bacteria, conferring antibiotic protection (Giguère et al., 2013).

Proteus spp. showed multiresistance in almost all isolates. It is unknown why this bacterium is capable of inducing multiresistance and creating mechanisms of antimicrobial protection, but 16 antimicrobial resistance genes have been described in bacteria of this genus. This gives them resistance to $\beta$-lactams, fluoroquinolones, streptomycin, tetracyclines, trimethoprim sulfate (Cheng et al., 2015).

In the case of Pseudomonas spp., crossresistance to antimicrobials and biofilm formation makes it difficult to contact the bacterium with the antibiotic and facilitates the creation of new resistance mechanisms through prolonged exposure at low doses (Pye et al., 2013).

Another bacterium that presented a high index of multiresistance was Staphylococcus spp. A feasible explanation for this high prevalence is that this genus may originate from humans, which receive antibiotic therapy more frequently, which increases the risk of resistance mechanisms on exposed bacteria (Huang et al., 2009). The resistance to $\beta$-lactam drugs in the genus Staphylococcus may be due to the presence of the $m e c$ A gene, which can be transmitted between the different coagulase-positive (Staphylococcus pseudintermedius and Staphylococcus aureus) and coagulase-negative (Staphylococcus equorum, Staphylococcus felis and Staphylococcus gallinarum) bacteria (Giguère et al., 2013).

In addition, biofilm formation has recently been described in strains of the genus Staphylococcus isolated from dogs with otitis (Moreira et al., 2012), which, as explained in the case of Pseudomonas spp., decreases the amount of antibiotic to which they are exposed, facilitating generation of resistance (Pye et al., 2013).

\section{Conclusion}

It is concluded that Staphylococcus spp. and Proteus spp. are the main bacteria isolated from chronic and recurrent otitis in dogs; the most effective antibiotics for the treatment of external otitis are amicacin, neomycin, gentamicin and tobramycin, of the class of aminoglycosides and ciprofloxacin and enrofloxacin, of the quinolone class, respectively.

Gram-positive and Gram-negative strains of multiresistant bacteria for antimicrobials are commonly isolated in dogs with chronic otitis.

Due to this large multiresistance present in bacteria isolated in cases of chronic otitis, the use of empirical therapies is not recommended because of the high risk of an insufficient treatment response, as well as the possibility of creating new resistance.

\section{Declaration of interest}

The authors declared no potential conflicts of interest with respect to the research, authorship, and/or publication of this article.

\section{Ethics Committee}

This study was approved by the Committee of Ethics in the use of animals from PUCPR, under protocol number $519-2^{\text {nd }}$ version. 


\section{References}

Angus, J.C. Pathogenesis of otite externa: Understanding primary causes. Proceeding of the North American Veterinary Conference, Orlando, Florida, pp. 807-809, 2005.

Bauer, A.W.; Kirby, W.M.; Sherris, J.C.; Turck, M. Antibiotic susceptibility testing by a standardized single disk method. American Journal of Clinical Pathology, 45: 493496, 1966.

Bensignor, E. Aproximación a la otitis externa y a la otitis media. In: Foster, A.; Foils, C. (eds). Manual de dermatología en pequeños animales y exóticos. $2^{\text {nd }}$ ed. L'Hospitalet de Llobregat: Ediciones S., 2008. p. 143-153.

Bugden, D.L. Identification and antibiotic susceptibility of bacterial isolates from dogs with otitis externa in Australia. Australian Veterinary Journal, 91(1-2): 43-46, 2013.

Cheng, A.; Chuang, Y.C.; Sun, H.Y.; Sheng, W.H.; Yang, C.J.; Liao, C.H.; Hsueh, P.R.; Yang, J.L.; Shen, N.J.; Wang, J.T.; Hung, C.C.; Chen, Y.C.; Chang, S.C. Excess mortality associated with colistin-tigecycline compared with colistin-carbapenem combination therapy for extensively drugresistant Acinetobacter baumannii bacteremia: A multicenter prospective observational study. Critical Care Medicine, 43(6): 1194-1204, 2015.

Cole, L.K. Anatomy and physiology of the canine ear. Veterinary Dermatology, 20: 412-421, 2009.

Cole, L.K. Otitis externa. In: Greene, C.E. Infectious diseases of the $\mathrm{dog}$ and cat. $4^{\text {th }}$ ed. St Louis: Elsevier Saunders, 2012. p. 885-892.

Colombini, S.O. Dermatología: enfermedades pruríticas de la piel en perros y gatos. $1^{\text {st }}$ ed. Delaware: The Gloyd Group, 2005. 68 p.

Daniel, S.J.; Munguia, R. Ototoxicity of topical ciprofloxacin/dexamethasone otic suspension in a chinchilla animal model. Otolarygology-Head and Neck Surgery, 139: 840-845, 2008.

Giguère, S.; Prescott, J.F.; Dowling, P.M. Antimicrobial therapy in veterinary medicine. Iowa: Wiley Blackwell, 2013.

Girão, M.D.; Prado, M.R.; Brilhante, R.S.N.; Cordeiro, R.A.; Monteiro, A.J.; Sidrim, J.J.C.; Rocha, M.F.G. Malassezia pachydermatis isolated from normal and diseased external ear canals in dogs: A comparative analysis. The Veterinary Journal, 172: 544-548, 2006.

Gotthelf, G.N. Doenças do ouvido em pequenos animais. $2^{a}$ ed. São Paulo: Editora Roca, 2007. 356p.

Griffin, C.E. Diagnosis of otitis externa and media - The PSPP approach. Proceedings of the $27^{\text {th }}$ Annual Congress of the Esvid-Ecvd; 2014a; Set 11-13; Salzburg, Austria. p. 2426.

Griffin, C.E. Medical treatment of otitis. Proceedings of the $27^{\text {th }}$ Annual Congress of the Esvid-Ecrd; 2014b; Set 11-13; Salzburg, Austria. p. 32-34.

Hariharan, H.; Coles, M.; Poole, D.; Lund, L.; Page, R. Update on antimicrobial susceptibilities of bacterial isolates from canine and feline otitis externa. Canadian Veterinary Journal, 47: 253-255, 2006.

Harvey, R.G.; Harari, J.; Delauche, A.J. Doença do ouvido em cães e gatos. Rio de Janeiro: Revinter, 2004. 272 p.

Huang, J.T.; Abrams, M.; Tlougan, B.; Rademaker, A.; Paller, A.S. Treatment of Staphylococcus aureus colonization in atopic dermatitis decreases disease severity. Pediatrics, 123: e808-e814, 2009.

Jacobson, L.S. Diagnosis and medical treatment of otitis externa in the dog and cat. Journal of the South African Veterinary Association, 73(4): 162-170, 2002.

Lemke, L.E.; McGee, D.H.; Prieskorn, D.M.; Wall, G.M.; Dolan, D.F.; Altschuler, R.A.; Miller, J.M. Safety of ciprofloxacin and dexamethasone in the guinea pig middle ear. Archives of Otolaryngology-Head \& Neck Surgery, 135(6): 575-580, 2009.

Luz, G.P.; Anater, A.; Ribeiro, D.R.; Fraiz, F.V.; Bárcena, J.; Kung, D.C.; Farias, M.R.; Pimpão, C.T. Avaliação da eficácia da associação de tiabendazol, sulfato de neomicina, dexametasona e cloridrato de lidocaína no tratamento da otoacaríase. Ciências Agrárias e Ambientais (Online), 12(4): 260-269, 2014.

Magiorakos, A.P.; Srinivasan, A.; Carey, R.B.; Carmeli, Y.; Falagas, M.E.; Giske, C.G.; Harbarth, S.; Hindler, J.F.; Kahlmeter, G.; Olsson-Liljequist, B.; Paterson, D.L.; Rice, L.B.; Stelling, J.; Struelens, M.J.; Vatopoulos, A.; Weber, J.T.; Monnet, D.L. Multidrug-resistant, extensively drug- 
resistant and pandrug-resistant bacteria: An international expert proposal for interim standard definitions for acquired resistance. Clinical Microbiology and Infection, 18(3): 268-281, 2012.

Malayeri, H.Z.; Jamshidi, S.; Salehi, T.Z. Identification and antimicrobial susceptibility patterns of bacteria causing otitis externa in dogs. Veterinary Research Communications, 34: 435-444, 2010.

Marinho, P.V.T.; Nunes, G.D.L.; Filgueira, F.G.F.; Tavares, T.H.; Silva, C.M.A.; Leite, A.R.A.; Carneiro, R.S.; Garino Júnior, F. Multirresistência bacteriana em cães com otite bilateral crônica recidivante (Relato de caso). Anais da IX Jornada de Ensino, Pesquisa e Extensão, 2009; Out 19-23; Pernambuco, Brasil. p. 1-3.

Matousek, J.L. Diseases of the ear pinna. Veterinary Clinic of North American Small Animal Practice, 34(2): 511-540, 2004.

Miller, W.; Griffin, C.; Campbell, K. Muller and Kirk's small animal dermatology. $7^{\text {th }} \mathrm{ed}$. Philadelphia: WB Saunders, 2013.

Moraes, L.F.; Takahira, R.K. Aplasia medular em cães. Revista de Ciências Agroveterinárias, 9(1): 99-108, 2010.

Moreira, C.A.; Oliveira, L.C.; Mendes, M.S.; Santiago, T.M.; Barros, E.B.; Carvalho, C.B.M. Biofilm production by clinical Staphylococci strains from canine otitis. Brazilian Journal of Microbiology, 43(1): 371-374, 2012.

Morris, D.O. Medical therapy of otitis externa and otitis media. Veterinary Clinics of North American Small Animal Practice, 34(2): 541-555, 2004.

Oliveira, L.C.; Medeiros, C.M.O.; Silva, I.N.G.; Monteiro, A.J.; Leite, C.A.L.; Carvalho, C.B.M. Susceptibilidade a antimicrobianos de bactérias isoladas de otite externa em cães. Arquivo Brasileiro de Medicina Veterinária e Zootecnia, 57(3): 405-408, 2005.

Oliveira, L.C.; Leite, C.A.L.; Brilhante, R.S.N.; Carvalho, C.B.M. Comparative study of the microbial profile from bilateral canine otitis externa. Canadian Veterinary Journal, 49: 785-788, 2008.

Penna, B.; Varges, R.; Medeiros, L.; Martins, G.M.; Martins, R.R.; Lilenbaum, W. Species distribution and antimicrobial susceptibility of Staphylococci isolated from canine otitis externa. Veterinary Dermatology, 21: 292296, 2009.

Penna, B.; Thomé, S.; Martins, R.; Martins, G.; Lilenbaum, W. In vitro antimicrobial resistance of Pseudomonas aeruginosa isolated from canine otitis externa in Rio de Janeiro, Brazil. Brazilian Journal of Microbiology, 42: 1434-1436, 2011.

Petrie, A.; Watson, P. Estatística em ciência animal e veterinária. $2^{\mathrm{a}}$ ed. São Paulo: Roca, 2009. 248 p.

Pye, C.C.; Yu, A.A.; Weese, J.S. Evaluation of biofilm production by Pseudomonas aeruginosa from canine ears and the impact of biofilm on antimicrobial susceptibility in vitro. Veterinary Dermatology, 24(4): 446449, 2013.

Quinn, P.J.; Markey, B.K.; Leonard, F.C.; Hartigan, P.; Fanning, S.; FitzPatrick, E.S. Veterinary microbiology and microbial disease. $2^{\text {nd }}$ ed. Oxford: Willey-Blackwell, 2011.

Rang, H.P.; Dale, M.M.; Ritter, J.M.; Flowe, R.J.; Henderson, G. Fármacos Antibacterianos. In: Rang, H.P.; Dale, M.M.; Ritter, J.M.; Flowe, R.J.; Henderson, G. Rang \& Dale farmacologia. $7^{\mathrm{a}}$ ed. São Paulo: Elsevier, 2010. p. 622-637.

Saridomichelakis, M.N.; Farmaki, R.; Leontides, L.S.; Koutinas, A.F. Aetiology of canine otitis externa: A retrospective study of 100 cases. Veterinary Dermatology. 18(5): 341-343, 2007.

Wooltorton, E. Ototoxic effects from gentamicin ear drops. Canadian Medical Association, 167(1): 56, 2002.

Zur, G. Otitis externa en el perro. Consulta de Difusión Veterinaria, 22(212): 35-42, 2014. 